\title{
Smoking behaviour among male students in a Saudi University
}

Guoping Jiang ${ }^{1}$, Shafi Aldamer ${ }^{2}$ and Ahmed Bendania ${ }^{2}$

Department of Sociology, Nanchang University, Nanchang, China (Correspondence to: G. Jiang: jiang@kfupm.edu.sa, jiangguoping@ncu.edu.cn). ${ }^{2}$ Department of General Studies, King Fahd University of Petroleum and Minerals, Dhahran, Saudi Arabia.

\begin{abstract}
Background: Smoking among university students is a social and public health problem worldwide. There is a high prevalence of smoking in Saudi Arabia.
\end{abstract}

Aims: To investigate the factors associated with the onset and cessation of smoking behaviour among university students in Saudi Arabia, and establish what contributes to changes of students' smoking behaviour.

Methods: A sample of 340 students from a national university in Saudi Arabia was randomly recruited and surveyed twice at a 5-month interval. Multiple ordinal logistic regression was run to compare changes in social, psychological and political factors and their impact on students' smoking behaviour.

Results: We found that beliefs supporting nonsmoking (e.g., religious prohibition of smoking) correlated with changes in smoking behaviour among university students [adjusted odds ratio (AOR) $=1.89,95 \%$ confidence interval $(\mathrm{CI})=1.23-$ 2.91]. There was a significant positive correlation between government policy and changes in male university students' smoking behaviour $(\mathrm{AOR}=0.46,95 \% \mathrm{CI}=0.29-0.072)$. The psychological effect of smoking, such as releasing psychological pressures, was also correlated with changes in smoking behaviour ( $\mathrm{AOR}=0.31,95 \% \mathrm{CI}=0.21-0.47$ ).

Conclusions: Our study suggests that the government can play a significant role in curbing smoking by strengthening beliefs promoting antismoking among university students, by developing corresponding policies against smoking, and by providing psychological consultation for them.

Keywords: Smoking, tobacco, cessation, ordinary logit analysis, Saudi Arabia,

Citation: Jiang G; Aldamer S; Bendania A. Smoking behaviour among male students in a Saudi University. East Mediterr Health J. $2018 ; 24(5): 411-418$. https://doi.org/10.26719/2018.24.5.411

Received: 05/04/16; accepted: 16/02/17

Copyright (c) World Health Organization (WHO) 2018. Some rights reserved. This work is available under the CC BY-NC-SA 3.0 IGO license (https:// creativecommons.org/licenses/by-nc-sa/3.o/igo).

\section{Introduction}

Tobacco smoking remains an important threat to public health. Almost 5 million deaths per year are related to smoking worldwide and the figure is expected to rise to 10 million by 2030 (1). Although such risky behaviour is denounced religiously in Saudi Arabia because of the self-destructiveness and financial waste attributed to smoking, smoking is common among Saudi citizens. Saudi Arabia is ranked 8th in the world for tobacco consumption, although it only involves a small percentage of the population (2).

There has only been a limited number of studies on Saudis' smoking behaviour; therefore, a more comprehensive study is needed for the following reasons. Social, government and psychological factors were ignored in previous studies. For instance, the Saudi Government ratified the World Health Organization (WHO) Framework Convention on Tobacco Control (FCTC) in 2005 (3), and they banned tobacco advertisements in local media. Sponsorship of sport by tobacco companies was banned and tobacco tax was increased in the late 1990s (4). Recently, King Salman issued the strictest royal decree against smoking, which banned smoking in the vicinity of religious, educational, health, sport and cultural institutions, as well as, social and charity institutions; the ban is also enforced in the workplace, government offices, factories, banks and all public transportation facilities (5). Unfortunately, there have been no empirical studies on the impact of such changes on Saudis' smoking behaviour. The limited number of previous studies were based on a cross-sectional design, therefore, it was not possible to track changes in smoking behaviour and the impact of environmental changes on smoking behaviour. They also focused on the onset of smoking while ignoring its cessation (6). Social environments that influence male college students' smoking behaviour have not received much attention either. Students move from a strictly controlled family/ high school environment to a less strictly controlled university environment. Such a new social environment can give rise to some factors that are more or less associated with smoking, such as "attachment to society via social connections", "commitment to be a good social member", "involvement in work or study", "association with smoking or nonsmoking people", "differential reinforcement by surrounding people", "imitation of smoking behaviour", and "awareness of health risk". However, despite the social environment becoming freer, it has become more regulated to control smoking behaviour. Since 2000, smoking has been forbidden in government buildings, educational institutions and healthcare facilities, and new regulations in 2013 banned smoking in all public areas (7). Therefore, we conducted 
a timely comprehensive study using a panel design of Saudi university students' smoking behaviour. We aimed to explain changes in Saudis' smoking behaviour from social, psychological and institutional perspectives.

Saudi university students live in a dynamic environment from which they receive influence, information, encouragement, support, pressure and constraints. Changes in smoking behaviour (either from being a nonsmoker to a smoker or from being a smoker to quitting) are embedded in such influences from social pressure and conditioned by constraints. Hence, the present study considered the following alternative hypotheses: (Hypothesis 1) attachment, commitment, involvement and beliefs as mechanisms of social control have a significant impact on Saudi male university students' smoking onset or cessation; (Hypothesis 2) the process of social learning, including association with, attitudes towards, and imitation of smokers, may change Saudi male university students' smoking behaviour; (Hypothesis 3) increased awareness regarding health risks of smoking is associated with a higher likelihood of quitting smoking among Saudi university students, while decreased awareness is associated with a lower likelihood of quitting or a higher likelihood of smoking onset; (Hypothesis 4) government policy on tobacco control prompts changes in Saudi male university students' smoking behaviour, which means that, while strict policies trigger quitting, loose policies may facilitate smoking initiation; and (Hypothesis 5) positive psychological functions of smoking, including stress relief, increase in confidence and feeling of pride, influence the change in Saudi male university students' smoking behaviour.

\section{Methods}

\section{Study design}

The panel study design benefits from longitudinal as well as cross-sectional elements and compares a cohort at 2 different points in time (8). In this study, it was adopted to establish which factors changed for each Saudi male university student, and how the changed factor influenced his smoking behaviour. Data were collected at the beginning (week 2; Time 1) and end (week 15; Time 2) of an academic semester with the same questionnaire. Data were processed with Stata version 13.

\section{Study sample}

Study samples were randomly drawn with cluster sampling methods from a male-only Saudi university that recruits students from across the nation. Fourteen classes (380 students) were randomly drawn from the registrar list of all classes of the semester at which the study took place. Three hundred and forty responses to the questionnaire were valid and matched for Time 1 and Time 2, and then processed for data analysis. The class breakdown of respondents were: sophomore (66 students, 19.41\%), junior (162 students, $47.65 \%$ ) and senior (98 students, $28.82 \%$ ). Age of respondents ranged from 18 to 26 years, with the majority ( 272 students, $80 \%$ ) between 21 and 23 years. The mean age was 22.08 with a standard deviation of 1.26.

\section{Measurement scales}

The questionnaire was based on 5 factors following the theoretical framework based on social learning theory, social control theory, institutional efforts, awareness of common health risks, and common psychological functions of smoking. The questionnaire assumed that students lived in a social environment within which they received influence, information, encouragement, support, pressure and constraints. Various studies have dealt with the factors in the theoretical framework and the reported tools were found to be valid and reliable (9). Scales were composed referring to those studies.

Social control, one of the main independent variables, was assessed with 4 scales that were borrowed from Hirschi (10); namely, attachment (attached to society or not; e.g., I have a lot of close friends); commitment (committed to a good social member or not; e.g., I behave well; therefore, my teachers think I am a good student); involvement (occupied with various activities or not, e.g.; I have not much time to have fun like smoking cigarettes); and belief (having a belief in nonsmoking or not; e.g., smoking in my culture is considered to be self-harming).

Social learning, the second independent variable, was assessed with 3 scales that were developed from the study of Petraitis et al. (11); namely, scale of differential association (close friends or family members' attitude towards smoking; e.g., my friends around me smoke); differential reinforcement (close friends or family members' attitude towards smoking; e.g., my image looks bad in people's eyes if I smoke); and imitation (see people smoking or not; e.g., I see my friends smoking).

The last 3 independent variables had only 1 scale each, with a varying number of questions, ranging between 3 and 5. They were awareness of health risk (e.g., smokingrelated diseases are difficult to be cured); government policy on tobacco control (e.g., I have seen many antismoking advertisements recently); and psychological function of smoking (e.g., smoking relieves me from stress).

The above scales were Likert-type questions, with " 1 " representing "strongly disagree" and "7" representing "strongly agree". Questionnaire reliability was tested with Cronbach's a (Table 1), and was found to be in the acceptable range (12).

The dependent variable was ordinal reported smoking status. Answers were coded in order with o representing "smoking", 1 "smoked but quit", and 2 "never smoked".

Ordinal panel data logistic regression was used to find the impacts that social environmental changes had on changes in students' smoking behaviour. Given the imprecise estimation of stepwise regression and unavailability of logistic regression for panel data in Stata, backward logistic regression was adopted in data analysis to find a parsimonious model that could explain Saudi male university students' smoking behaviour with the least number of predictor variables. 


\begin{tabular}{|c|c|c|c|}
\hline $\begin{array}{l}\text { Table i Spearman's } \rho \text { between } \\
\text { smoking behaviour among } \mathrm{m}\end{array}$ & $\begin{array}{l}\text { predicto } \\
\text { le Saudi }\end{array}$ & $\begin{array}{l}\text { variables } \\
\text { niversity }\end{array}$ & $\begin{array}{l}\text { and changes in } \\
\text { students }\end{array}$ \\
\hline Predictor variable & Spear & ran's $\rho$ & Cronbach's $\alpha$ \\
\hline & Time 1 & Time 2 & \\
\hline Social control & & & \\
\hline Attachment & -0.09 & 0.01 & 0.591 \\
\hline Commitment & $0.33^{*}$ & $0.20^{*}$ & 0.810 \\
\hline Involvement & 0.11 & 0.14 & 0.599 \\
\hline Belief & $0.48^{*}$ & $0.26^{*}$ & 0.661 \\
\hline Social learning & & & \\
\hline Differential association & $-0.21^{*}$ & -0.05 & 0.565 \\
\hline Differential reinforcement & -0.06 & -0.01 & 0.641 \\
\hline Imitation & $-0.23^{*}$ & $-0.23^{*}$ & 0.553 \\
\hline Awareness of health risk & $-0.21^{*}$ & $-0.35^{*}$ & 0.617 \\
\hline Governmental policy & $-0.30^{*}$ & $-0.18^{*}$ & 0.625 \\
\hline Psychological functions & $-0.51^{*}$ & $-0.51^{*}$ & 0.630 \\
\hline
\end{tabular}

\section{Results}

\section{Smoking status}

Among all respondents, $72(21.18 \%)$ students reported smoking at Time 1 . This number increased to 106 (31.18\%) at Time 2. At Time 1, 244 (71.76\%) students never smoked, but this was reduced to $206(60.58 \%)$ at Time 2 . At Time $1,24(7.06 \%)$ students smoked but quit, and this number increased to $28(8.24 \%)$ at Time 2 . The changes in Saudi students' smoking behaviour between the 2 surveys were tested with the $\chi^{2}$ test, and were found to be significant (Pearson $\chi^{2}=5.0276, P=0.081$ ).

\section{Correlations between independent and dependent variables}

Correlation between independent variables and dependent variable smoking status was tested with Spearman's $\rho$. At Time 1, independent variables commitment and belief (Hypothesis 1), differential association and imitation (Hypothesis 2), health risk (Hypothesis 3), government policy (Hypothesis 4) and psychological function (Hypothesis 5) were significantly correlated with smoking status (Table 1). At Time 2, independent variables commitment and belief (Hypothesis 1), imitation (Hypothesis 2), health risk (Hypothesis 3), government interference (Hypothesis 4) and psychological function (Hypothesis 5) were significantly correlated with smoking status. These independent variables were therefore significantly associated with Saudi male university students' smoking behaviour.

\section{Ordered logit models}

Four ordinal logit models were tested with the longitudinal panel data to find the parsimonious one. Model 1 was fully loaded with all independent variables plus variable age and grade. Model 2 included independent variables (commitment, belief, imitation, health risk, government policy and psychological function) that were significant- ly correlated with dependent variable smoking status at Time 1 and Time 2, plus variable age and grade. Model 3 only embraced independent variables that were significant in Model 2. Model 4 was tested with independent variables that were significant in Model 3. All models were tested on proportional odds assumption and found to have met the assumption (Table 2).

Model 1 was statistically significant [log likelihood $\left(l(\theta \mid x)=199.44\right.$, likelihood ratio $(L R) \chi^{2}(12)=70.33$, $P<0.001$. Predictor variables age, grade, belief in nonsmoking (Hypothesis 2), differential association with surrounding people (Hypothesis 3), government policy (Hypothesis 4) and psychological function (Hypothesis 5) had a significant influence on changes in Saudi university students' smoking behaviour. Model 2 was also found to be statistically significant $(1(\theta \mid x)=-203.35$, LR $\chi 2(12)=$ 62.51, $P<0.001)$. Tested with likelihood ratio test statistic, Model 2 was proved to fit better than Model $1(P=0.0985)$. In the same manner, Model 3 was statistically significant (LR $\chi 2=57.26, P<0.001$ ), and fitted better than Model 2. Model 4 nested in Model 3 was statistically significant $\left(1\left(\theta \mid \mathrm{x}=-206.70371 ; \operatorname{LR}_{\chi 2}(3)=55.81 ; P<0.001\right)\right.$ and superior to Model 3 ( $\chi 2=1.44978, P=0.229)$. Therefore, it was regarded as the parsimonious model that explained best the impact of social environmental changes on Saudi male university students' smoking behaviour, with the least number of predictor variables. Hypotheses 4 and 5 were supported; Hypothesis 1 was partially supported because only the mechanism of control via belief had a significant influence on smoking; while Hypotheses 2 and 3 were rejected because Saudi university students did not initiate or quit smoking because of social influences and awareness of health risks.

In Model 4, for a 1-unit increase in independent variable belief, the odds of smoking versus the combined category of never smoked and smoked but quit were 1.89 times greater, given that all other variables in the model were held constant. Likewise, the odds of the combined category of smoking and smoked but quit versus never smoked were 1.89 times greater, given that all other variables in the model were held constant. For a 1-unit increase in independent variable government policy, the odds of smoking versus the combined category of never smoked and smoked but quit were 0.46 times greater, given that all other variables in the model were held constant. Because of the satisfaction of proportional odds assumption, the same increase was also found between never smoked and the combined category of smoking and smoked but quit. For a 1-unit increase in independent variable psychological function, the odds of smoking versus the combined category of never smoked and smoked but quit were 0.31 times greater, given that all other variables in the model were held constant. Likewise, the odds of the combined category of smoking and smoked but quit versus never smoked were 0.31 greater, given that all other variables in the model were held constant. The parsimonious model is illustrated in Figure 1. 


\begin{tabular}{|c|c|c|c|c|c|c|c|c|}
\hline \multirow[t]{2}{*}{ Variable } & \multicolumn{2}{|c|}{ Model 1} & \multicolumn{2}{|c|}{ Model 2} & \multicolumn{2}{|c|}{ Model 3} & \multicolumn{2}{|c|}{ Model 4} \\
\hline & AOR & $95 \% \mathrm{CI}$ & AOR & $95 \% \mathrm{CI}$ & AOR & $95 \% \mathrm{CI}$ & AOR & $95 \% \mathrm{CI}$ \\
\hline Age & $0.48^{*}$ & $0.26-0.89$ & $0.53^{*}$ & $0.29-0.97$ & 0.77 & $0.49-1.19$ & - & - \\
\hline Grade & $2.77^{*}$ & $1.14-6.70$ & 2.33 & $0.96-5.67$ & - & - & - & - \\
\hline \multicolumn{9}{|l|}{ Social control } \\
\hline Attachment & 0.87 & $0.53-1.42$ & - & - & - & - & - & - \\
\hline Commitment & 1.12 & $0.67-1.85$ & 1.03 & $0.64-1.68$ & - & - & - & - \\
\hline Involvement & 1.08 & $0.68-1.72$ & - & - & - & - & - & - \\
\hline Belief & $1.97^{*}$ & $1.21-3.19$ & $1.71^{*}$ & $1.07-2.74$ & $1.90^{*}$ & $1.24-2.92$ & $1.89^{*}$ & $1.23-2.91$ \\
\hline \multicolumn{9}{|l|}{ Social learning } \\
\hline Differential association & $1.95^{*}$ & $1.15-3.33$ & - & - & - & - & - & - \\
\hline Differential reinforcement & 1.39 & $0.75^{-2.58}$ & - & - & & & & \\
\hline Imitation & 0.68 & $0.42-1.12$ & 0.82 & $0.51-1.33$ & - & - & - & - \\
\hline Health risk & 0.72 & $0.40-1.31$ & 0.74 & $0.41-1.36$ & - & - & - & - \\
\hline Governmental policy & $0.42^{*}$ & $0.26-0.68$ & $0.46^{*}$ & $0.29-0.73$ & $0.46^{*}$ & $0.29-0.72$ & $0.46^{*}$ & $0.29-0.72$ \\
\hline Psychological function & $0.31^{*}$ & $0.20-0.48$ & $0.34^{*}$ & $0.22-0.52$ & $0.32^{*}$ & $0.21-0.48$ & $0.31^{*}$ & $0.21-0.47$ \\
\hline Test of prop. odds ASM & \multicolumn{2}{|c|}{$\chi^{2}=12.49(\mathrm{P}=0.41)$} & \multicolumn{2}{|c|}{$\chi^{2}=6.06(P=0.64)$} & \multicolumn{2}{|c|}{$\chi^{2}=2.89(P=0.58)$} & \multicolumn{2}{|c|}{$\chi^{2}=2.20(P=0.53)$} \\
\hline $\begin{array}{l}\text { Test of ordinal vs nonordinal } \\
\text { regression }\end{array}$ & \multicolumn{2}{|c|}{$\chi^{2}=20.13^{* *}$} & \multicolumn{2}{|c|}{$\chi^{2}=23.98^{* *}$} & \multicolumn{2}{|c|}{$\chi^{2}=26.97^{* *}$} & \multicolumn{2}{|c|}{$\chi^{2}=26.68^{* *}$} \\
\hline Likelihood ratio $\chi^{2}$ & \multicolumn{2}{|c|}{$70.33^{* *}$} & \multicolumn{2}{|c|}{$62.51^{* *}$} & \multicolumn{2}{|c|}{$57.26^{* *}$} & \multicolumn{2}{|c|}{$55.81^{* *}$} \\
\hline Log likelihood & \multicolumn{2}{|c|}{$-199.44^{* *}$} & \multicolumn{2}{|c|}{$-203.35^{* *}$} & \multicolumn{2}{|c|}{$-205.98^{* *}$} & \multicolumn{2}{|c|}{$-206.70^{* *}$} \\
\hline
\end{tabular}

${ }^{*} \mathrm{P}<0.05 ;{ }^{* *} \mathrm{P}<0.001$. prop. odds $\mathrm{ASM}=$ proportional odds assumption.

\section{Discussion}

Smoking behaviour is influenced by various factors. Our panel study demonstrated that belief in nonsmoking, government policy on tobacco control, and psychological function of smoking were significant predictors for changes in smoking behaviour among Saudi male university students. On the contrary, attachment to society via social connections, commitment to be a good social member, involvement in work or study, association with smoking or nonsmoking people, differential reinforcement by surrounding people, imitation of smoking, and awareness of health risk did not contribute to understanding changes in Saudi university students' smoking behaviour. Hence, social control theory was partially supported, while social learning theory was not.

Antismoking attitude was found to have the most important influence on tobacco use in some western and eastern countries, such as Hungary (13), Korea (14) and the United States of America (15). However, Islam does not approve of smoking for health and financial reasons. Saudi Arabia has a deeply rooted religious culture. Islam is internalized in its practitioners, therefore, antismoking attitude is ideally supposed to be part of Saudi consciousness. Religious conviction has been the most important reason for not or quitting smoking in some Saudi studies (16). Such a finding was also demonstrated in the present study. Belief in nonsmoking is 1 of 3 variables that had a significant impact on changing smoking behaviour. Those who held a weak attitude towards nonsmoking from an Islamic perspective might have smoked, while those whose attitude was strong might have quit smoking. It should be noted that antismoking attitude in Saudi Arabia differs from that in other countries because, it is forbidden religiously. Therefore, antismoking attitudes are stronger and imbued with meaning for Muslims, which may not be the case for non-Muslims.

Our findings are consistent with studies from other countries regarding government role in curbing smoking (17). However, in comparison to western countries, the Saudi government has not taken systematic punitive measures against smoking. The Saudi Government has had some sporadic policies, such as ratification of the WHO FCTC in 2005, ban on tobacco advertisements in local media, smoking ban in health and education facilities and public transportation areas (18), ban on sponsorship of sport by tobacco companies (18), and tobacco tax increase in the 1990s (4). The present study shows that such controls may reduce tobacco use among Saudi male university students. If the Saudi Government were to put more effort into developing systematic antismoking policies, smoking prevalence would be reduced significantly.

The present study showed that Saudi male university students have low awareness of the health risks of smoking. This is consistent with a finding on water-pipe smoking from a sample of Eastern Saudi secondary school 
Figure 1 Parsimonious model of impact of social environments on changes in Saudi male university students' smoking behaviour

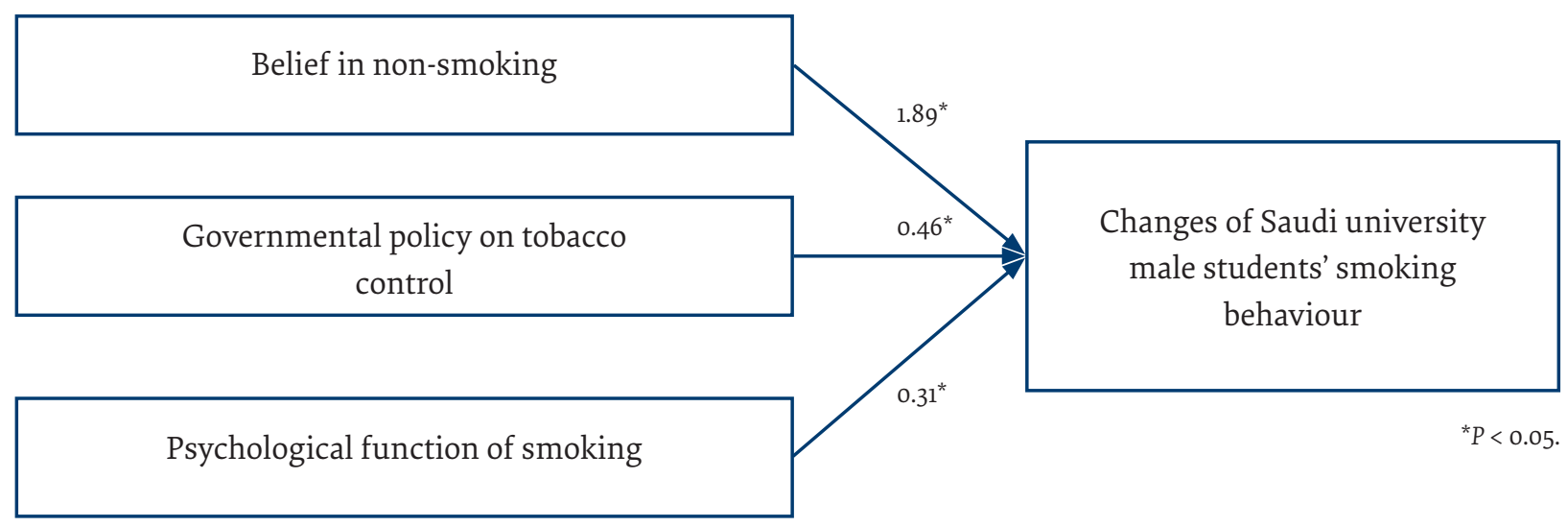

adolescents (19), but differs from the results from western studies (20). Social and school education on antismoking without detailed knowledge about the relationship of mortality to smoking in Saudi Arabia might not produce an effective outcome. It has been demonstrated in European studies that a person who is aware of the mortality consequences of smoking smokes less than a person who believes that the effect is reversible (21), but such a conclusion was not confirmed in the present study. It is possible that Saudi male university students use some explanations such as moderate use is not harmful, counter-evidence, and compensatory behaviour to justify their smoking and to protect themselves from self-blame as well as blame from others, as discovered in a Finnish study (22).

Smoking has been found to start via behavioural mechanisms such as differential association, differential reinforcement, and imitation of western and Asian populations (23). However, these mechanisms had no significant impact on changing smoking behaviour in the present study, in contrast to 2 studies on medical students in Saudi Arabia, in which peer influence was significantly associated with smoking onset (24). In contrast to some western societies in which there are social climates encouraging smoking at a young age (25), there is no cultural reward or expectation for smoking in an Islamic social environment. Therefore, even if they are surrounded by smokers, Saudi male university students do not feel pressure from them for smoking is denounced culturally in the Kingdom.

As a result of recent rapid urbanization and migration, psychological problems have started to become an issue in Saudi Arabia (26). Although recognition and treatment of mental health disorders have made marked progress in Saudi Arabia (27), some Saudis release stress and anxiety through tobacco use (18). Our study confirmed that psychological problems such as depression play a significant role in changes in smoking behaviour, which is consistent with findings from western and East Asian countries (28-31). In contrast to the above findings, in the present study, Saudi male university students smoked to improve their psychological wellbeing, such as gaining pride or confidence, while not having any indications of psychological distress.

In studies of non-Muslim societies, tobacco use was associated with other risky behaviours, such as alcohol use, hazardous driving, relational abuse, fighting, dislike of school, and illicit drug use $(28,32)$, which were not tested in our study. It could be assumed that alcohol use is not related to tobacco use in Saudi Arabia because alcohol is not legally available in the country. However, it is possible that smoking is related to hazardous driving in Saudi Arabia because Saudis are known for their recklessness behind the wheel (33).

The present study shows that smoking can be curbed in Saudi Arabia. Specifically, the Saudi Government can reduce prevalence of smoking by strengthening religious education on nonsmoking; developing systematic measures for tobacco control, including education, communication, training and public awareness in line with the FCTC Article 12 (34); and providing cessation services including psychological consultation as well as social services.

There were some limitations to the present study. First, as the sample was drawn from students of a male university, the conclusion may not be generalized to the whole adolescent Saudi population. A study of adolescence with less education could help draw a more general conclusion and help understand the impact of education on smoking behaviour. It has been discovered that there is a greater likelihood of smoking among individuals with low education level (4). Second, the time gap between the 2 rounds of data collection might not have been long enough to discover changes in social settings. It could be more revealing to extend the period as attitudes on smoking may be affected temporally. Third, the current study only collected data from male Saudi university students, therefore the conclusion may not be generalized to female students. A follow-up study on female university students' smoking behaviour could help to show the impact of gender on smoking behaviour, given that it is common for Saudi women to smoke shisha or cigarettes, especially when shisha is somehow acceptable in Saudi Arabia (35). 
Study at university is an important period in which adolescents start or stop smoking. Prior studies from the Middle East have tackled the causes from a medical perspective with multivariate regression, but little is known from a sociological perspective. The present study helped to establish the causes of changes in smoking behaviour among Saudi male students. Our ordinal logistic regres- sion analysis revealed that belief in nonsmoking, governmental policy, and positive psychological effects of smoking are the most important predictors of smoking onset and cessation. Smoking prevalence can be reduced by strengthening nonsmoking beliefs, restricting smoking in public areas, raising tobacco tax, and providing psychological consultations for people under pressure.

Funding: The study was funded by King Fahd University of Petroleum and Minerals. Grant ID: IN111055.

Competing interests: None declared.

\section{Comportements tabagiques chez des étudiants de sexe masculin dans une université en Arabie saoudite}

\section{Résumé}

Contexte : Le tabagisme chez les étudiants à l'université constitue un problème social et de santé publique partout dans le monde. La prévalence du tabagisme est élevée en Arabie saoudite.

Objectif : La présente étude avait pour objectif d'étudier les facteurs associés à la mise en route ou l'arrêt du tabagisme parmi les étudiants à l'université en Arabie saoudite, ainsi que de déterminer ce qui contribue à modifier leurs comportements tabagiques.

Méthodes : Un échantillon de 340 étudiants issus d'une université nationale en Arabie saoudite a été sélectionné au hasard et étudié à deux reprises à cinq mois d'intervalle. Une régression logistique ordinale multiple a été menée afin de comparer les changements en termes de facteurs sociaux, psychologiques et politiques, ainsi que leur impact sur les comportements tabagiques des étudiants.

Résultats : Nous avons constaté une corrélation entre les croyances antitabac (telles que l'interdiction religieuse de fumer) et les changements des comportements tabagiques chez les étudiants à l'université (odds ratio ajusté $=1,89$, intervalle de confiance $[\mathrm{IC}]$ à $95 \%=1,23-2,91)$. Il existait une corrélation positive significative entre les politiques gouvernementales et les changements de comportements tabagiques chez les étudiants de sexe masculin à l'université (odds ratio ajusté = 0,46, IC à $95 \%$ = 0,29-0,072). L'effet psychologique du tabagisme, tel que soulager la pression psychologique, était également corrélé aux changements de comportements tabagiques (odds ratio ajusté =0,31, IC à 95\%=0,21-0,47).

Conclusion : Cette étude suggère que le rôle du gouvernement pour infléchir le tabagisme peut être significatif s'il permet de renforcer les croyances de promotion antitabac parmi les étudiants à l'université, de mettre au point des politiques de lutte antitabac correspondantes et de mettre à leur disposition un système de consultations psychologiques.

$$
\begin{aligned}
& \text { سلو ك التدخين بين طلاب الجامعات الذكور في المملكة العربية السعودية } \\
& \text { جوبنج جيانج، شافي الدامر، أحمد بن دانية } \\
& \text { الخالاصة } \\
& \text { الخلفية: يمثل التدخين مشكلة اجتماعية وصحية بين الطلاب الجامعيين. هناك معدلات انتشار عالية للتدخين في المملكة العربية السعودية. } \\
& \text { الأهداف: هدفت هذه الدراسة إلى التعرف على عو امل بداية ممارسة التدخين والإقلاع عنه بين الطلاب الجامعيين في المملكة العربية السعودية، }
\end{aligned}
$$

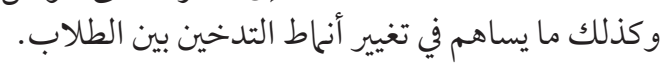

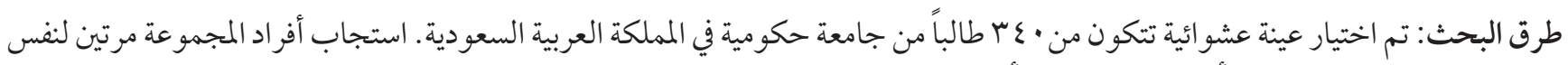

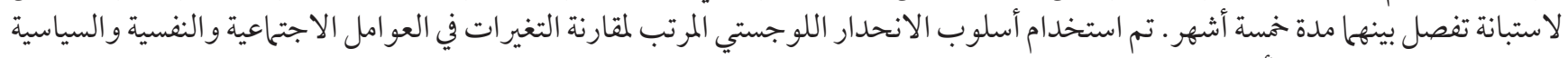

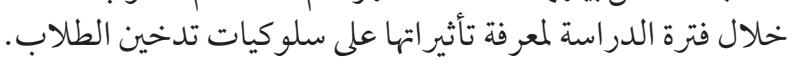

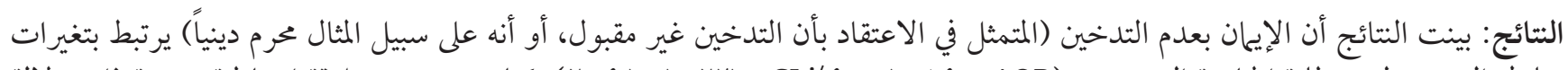

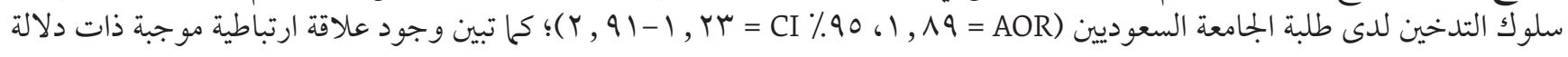

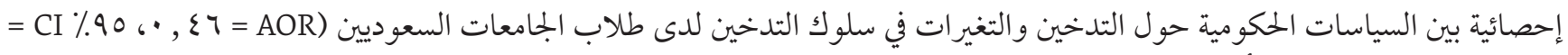

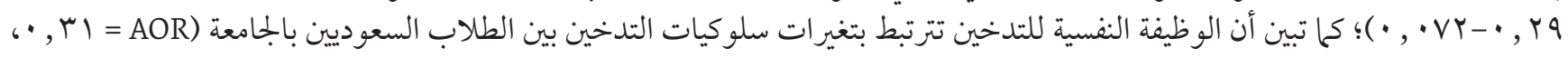

$$
\begin{aligned}
& \text {.( }, \varepsilon V-\cdot, r)=C I \% 90
\end{aligned}
$$

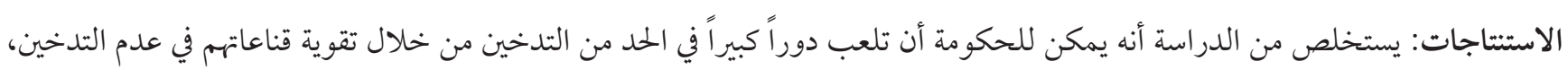

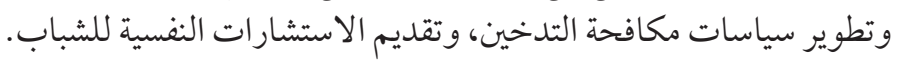




\section{References}

1. Jha P, Chaloupka F, editors (2011). Tobacco control in developing countries. Washington: World Bank; 2012 (http://documents. worldbank.org/curated/en/602821468330954036/pdf/709670WPotobacooBox370064BooPUBLICo.pdf, accessed 18 December 2017).

2. Alnohair SF. Prevalence of smoking and its related behaviors and beliefs among secondary school students in Riyadh, Saudi Arabia. Int J Health Sci. 2011;5(1):57-63.

3. WHO Framework Convention on Tobacco Control. Geneva: World Health Organization; 2005 (http://apps.who.int/iris/bitstream/10665/42811/1/9241591013.pdf?ua=1, accessed 19 December 2017).

4. Jarallah JS, al-Rubeaan KA, al-Nuaim ARA, al-Ruhaily AA, Kalantan KA. Prevalence and determinants of smoking in three regions of Saudi Arabia. Tob Control. 1999 Spring;8(1):53-6. http://dx.doi.org/10.1136/tc.8.1.53 PMID:10465816

5. Alshibrawi A. (2016). Smoking ban in public areas takes effect. Saudi Gazette. 13 June 2016. (https://english.alarabiya.net/en/variety/2016/06/13/Smoking-ban-in-public-areas-takes-effect-in-Saudi-Arabia.html; accessed 27 December 2017).

6. Uyar M, Filiz A, Bayram N, Elbek O, Herken H, Topcu A, et al. A randomized trial of smoking cessation. Medication versus motivation. Saudi Med J. 2007 Jun;28(6):922-6. PMID:17530112

7. Mason WM, Wolfinger NH. Cohort Analysis. In: Smelser J, Baltes PB, editors. International encyclopaedia of the social \& behavioral sciences. Oxford University Press; 2001:2189-94. http://dx.doi.org/10.1016/Bo-08-043076-7/00401-0

8. Duncan GJ. Panel Surveys: Uses and applications. In: Pergamon N, editor. International encyclopaedia of the social \& behavioral sciences. Oxford University Press; 2001:11009-15. http://dx.doi.org/10.1016/Bo-08-043076-7/00748-8

9. Ferrante M, Saulle R, Ledda C, Pappalardo R, Fallico R, La Torre G, et al. Prevalence of smoking habits, attitudes, knowledge and beliefs among Health Professional School students: a cross-sectional study. Ann Ist Super Sanita. 2013;49(2):143-9. http://dx.doi. org/10.4415/ANN_13_02_06 PMID:23771259

10. Hirschi T. Causes and prevention of juvenile delinquency. Sociol Inq. 1977;47(3-4):322-41. http://dx.doi.org/10.1111/j.1475682X.1977.tboo804.X

11. Petraitis J, Flay BR, Miller TQ. Reviewing theories of adolescent substance use: organizing pieces in the puzzle. Psychol Bull. 1995 Jan;117(1):67-86. http://dx.doi.org/10.1037/0033-2909.117.1.67 PMID:7870864

12. Sijtsma K. On the use, the misuse, and the very limited usefulness of Cronbach's alpha. Psychometrika. 2009 Mar;74(1):107-20. http://dx.doi.org/10.1007/s11336-008-9101-o PMID:20037639

13. Piko B. Smoking in adolescence do attitudes matter? Addict Behav. 2001 Mar-Apr;26(2):201-17. http://dx.doi.org/10.1016/So3064603(00)00101-5 PMID:11316377

14. Kim MS. [A study on health-related quality of life, smoking knowledge, smoking attitude, and smoking cessation intention in male smokers]. J Korean Acad Nurs. 2005 Apr;35(2):344-52 (in Korean). http://dx.doi.org/10.4040/jkan.2005.35.2.344 PMID:15860948

15. Rhodes N, Roskos-Ewoldsen DR, Edison A, Bradford MB. Attitude and norm accessibility affect processing of anti-smoking messages. Health Psychol. 2008 May;27(3, Suppl) 3S:S224-32. http://dx.doi.org/10.1037/0278-6133.27.3(Suppl.).S224 PMID:18979975

16. Saeed AA, Khoja TA, Khan SB. Smoking behaviour and attitudes among adult Saudi nationals in Riyadh City, Saudi Arabia. Tob Control. 1996 Autumn;5(3):215-9. http://dx.doi.org/10.1136/tc.5·3.215 PMID:9035357

17. Weyers H. Smoking bans in the Netherlands: a mix of self-regulation and regulation by government. Legisprudence. 2010;4(3):327-42. http://dx.doi.org/10.1080/17521467.2010.11424717

18. Bassiony MM. Smoking in Saudi Arabia. Saudi Med J. 2009 Jul;30(7):876-81. PMID:19617999

19. Amin TT, Amr MAM, Zaza BO, Kaliyadan F. Predictors of waterpipe smoking among secondary school adolescents in Al Hassa, Saudi Arabia. Int J Behav Med. 2012 Sep;19(3):324-35. http://dx.doi.org/10.1007/s12529-011-9169-2 PMID:21643931

20. Tilleczek KC, Hine DW. The meaning of smoking as health and social risk in adolescence. J Adolesc. 2006 Apr;29(2):273-87. http:// dx.doi.org/10.1016/j.adolescence.2005.07.002 PMID:16125767

21. Carbone JC, Kverndokk S, Røgeberg OJ. Smoking, health, risk, and perception. J Health Econ. 2005 Jul;24(4):631-53. http://dx.doi. org/10.1016/j.jhealeco.2004.11.001 PMID:15960989

22. Heikkinen H, Patja K, Jallinoja P. Smokers' accounts on the health risks of smoking: why is smoking not dangerous for me? Soc Sci Med. 2010 Sep;71(5):877-83. http://dx.doi.org/10.1016/j.socscimed.2010.05.036 PMID:20619947

23. Akers RL, Lee G. A longitudinal test of social learning theory: adolescent smoking. J Drug Issues. 1996;26(2):317-43. http://dx.doi. org/10.1177/002204269602600203

24. Al-Turki YA. Smoking habits among medical students in Central Saudi Arabia. Saudi Med J. 2006 May;27(5):700-3. PMID:16680263

25. Byrne D, Reinhart M. Psychological determinants of adolescent smoking behaviour: A prospective study. Aust J Psychol. 1998;50(1):29-34. http://dx.doi.org/10.1080/00049539808257528

26. Al-Sughayr AM, Ferwana MS. Prevalence of mental disorders among high school students in National Guard Housing, Riyadh, Saudi Arabia. J Family Community Med. 2012 Jan;19(1):47-51. http://dx.doi.org/10.4103/2230-8229.94015 PMID:22518359 
27. Koenig HG, Al Zaben F, Sehlo MG, Khalifa DA, Al Ahwal MS, Qureshi NA, et al. Mental health care in Saudi Arabia: past, present and future. Open J Psychiatr. 2014;4(2):113-30. http://dx.doi.org/10.4236/ojpsych.2014.42016

28. Halperin AC, Smith SS, Heiligenstein E, Brown D, Fleming MF. Cigarette smoking and associated health risks among students at five universities. Nicotine Tob Res. 2010 Feb;12(2):96-104. http://dx.doi.org/10.1093/ntr/ntp182 PMID:20018947

29. Lawrence D, Mitrou F, Zubrick SR. Non-specific psychological distress, smoking status and smoking cessation: United States National Health Interview Survey 2005. BMC Public Health. 201104 22;11(1):256-69. http://dx.doi.org/10.1186/1471-2458-11-256 PMID:21513510

30. Maksimovic L, Paquet C, Daniel M, Stewart H, Chong A, Lekkas P, et al. Characterising the smoking status and quit smoking behaviour of aboriginal health workers in South Australia. Int J Environ Res Public Health. 2013 12 13;10(12):7193-206. http://dx.doi. org/10.3390/ijerph10127193 PMID:24351741

31. Weiss JW, Palmer PH, Chou C-P, Mouttapa M, Johnson CA. Association between psychological factors and adolescent smoking in seven cities in China. Int J Behav Med. 2008;15(2):149-56. http://dx.doi.org/10.1080/10705500801929825 PMID:18569133

32. Saingam D, Assanangkornchai S, Geater AF. Drinking-smoking status and health risk behaviors among high school students in Thailand. J Drug Educ. 2012;42(2):177-93. http://dx.doi.org/10.2190/DE.42.2.d PMID:23185837

33. Almulhim A. We need to change driving habits. Arab News. 23 December 2013 (http://www.arabnews.com/news/497091, accessed 19 December 2017).

34. The WHO Framework Convention on Tobacco Control: an overview. World Health Organization; 2015 (http://www.who.int/fctc/ WHO_FCTC_summary_January2015_EN.pdf, accessed 19 December 2017).

35. Fouad, D. 65\% of secondary schoolgirls smoke. Arab News. 9 February 2015 (http://www.arabnews.com/saudi-arabia/news/701331, accessed 19 December 2017). 